\title{
DEVELOP LEADERSHIP, MANAGEMENT AND PERFORMANCE ORGANIZATION ON INTRA-SCHOOL STUDENT ORGANIZATION (OSIS)
}

\author{
Harefan Arief, Mochamad Soelton, and Fatchur Rohman, and Rajab Ritonga \\ Universitas Mercu Buana Jakarta, Indonesia \\ Universitas Brawijaya, Indonesia \\ Universitas Prof. Dr. Moestopo (Beragama), Indonesia. \\ harefan.arief@mercubuana.ac.id
}

\begin{abstract}
Intra-School Student Organization (OSIS) is a means of developing students' interests and talents in the school's internal environment. The existence of the student council can be beneficial for schools and the community. OSIS is also a major component of the pioneering schoolfor developments in the school. The problem is that many student councils do not show their existence as a driving force in the development of schools and students. The student council vacuum is more due to the low understanding of management and leadership concepts, so that potential members cannot be managed properly. This community service activity is carried out by providing training and program assistance for 1 month. As a result of this activity is the increasing existence of OSIS in schools and is beneficial for students and the community as a forum for discussion in terms of increasing the existence of OSIS and contributing to human development.
\end{abstract}

Keywords: Management, Leadership, School

\section{INTRODUCTION}

Intra-School Student Organization (OSIS) is an organized group of students to create a school atmosphere that is not rigid and monotonous because of learning in the classroom. The balance of the students' left and right brains needs to be sharpened at school with a variety of available means. OSIS, its existence began in the new order as an effort so that students do not have or join a banned and deviant organization that is outside the school. The hope is that OSIS will be the student's main tool in self-development in organizational patterns.

Along with the times, student council in every school has decreased activity and creativity. Many factors can be used as reasons, ranging from the nature of adolescent hedonism, so they do not want to do for others to the low level of understanding of organizational management. The progress of an organization must be supported by an understanding of management and leadership concepts by the organization's policy stakeholders. Negligence on this understanding can lead to low organizational productivity in contributing.

Management is a concept for managing things while leadership is the ability of a person to influence other people to cooperate in accordance with the plan for the achievement of predetermined goals. Thus leadership plays a very important role in management in organizations or institutions, it can even be stated, leadership is the core of management. To realize this it is necessary to foster leadership since early on among students.

Students are part of the young generation of Indonesia. Students get a huge opportunity to develop themselves as human beings with quality and integrity. Students as educated people are young intellectuals who are expected to have high creativity both in the academic and non-academic fields. In the development process, students are the power of development which must be built at the same time so that they are capable of realizing a good future.

On the other hand, students also spearhead change of course there is in the generation of students who are educated like students at the upper secondary level (high school and MA). However, a paradox occurs, students who should be the spearhead of change in the positive direction, it is far from the desired expectations. If we ask parents, the right labels for students today are those who are not ready to be entrusted with trust be a leader. This certainly has a reason, where students are now closer to drugs, free sex, relationships that are not positive, and all negative behaviors attached to them. There is no hope to entrust a large mandate to them. Even if there is, it is only a small part. Many students are achievers, but sometimes they are not equipped with faith in their god. These unbelieving students will bring disaster to the future generation of this nation's leadership.

Students who later become agents of change and social control agents are pioneers and milestones of a social development and change. Students who have an understanding of leadership are expected to be able to become the nation's successors who change the face of the world later. Students are also identified with scholars who are able 
to think critically of all existing problems. Students are also closely related to organization and skills. Skills are something that students should master from an early age to be able to carry out their functions in life and organize properly.

For this reason, we need an activity that can train and guide students to become leaders who are smart, have character, have a vision of the future and have integrity. This activity is aimed at the board of senior high school student council in Kembangan, because the Intra-School Student Organization is a moment to reflect the commitment of change made by the educated generation in the midst of the scientific community, as well as contributing change towards a new generation of great and dignified Indonesia, then through generations young people who have an understanding of leadership in organizational management can all be realized.

Practicing leadership from an early age is a manifestation of national leadership going forward. At the discourse level, this training also aims to elevate the moral and moral perspective of a religious leader to build a new visionary, integrity, dynamic and civilized leadership. Furthermore, at the (practical) movement level, it is scheduled to carry a moral call for concern for the problems of the people and nation.

The problems of the current student council management are: First, the lack of student council management understanding to manage intra-school organizations. Secondly, there is no process of leadership regeneration at the school level carried out simultaneously or continuously. Third, there is a decrease in the level of activity of the management which can be seen from the low percentage of activities carried out each year. Based on these problems, the focus of the problem solved in this community service activity is to foster the management abilities and leadership characteristics of students

\section{LITERATURE REVIEW}

Organizational performance is an indicator of the level of achievement that can be achieved and reflects the success of an organization, and is the result achieved from the behavior of members of the organization. Performance can also be said as a result (output) of a certain process carried out by all components of the organization against certain sources used (input). Furthermore, performance is also the result of a series of process activities carried out to achieve certain organizational goals. For an organization, performance is the result of collaborative activities among members or components of the organization in order to realize organizational goals. The organization is a structure of the division of labor and structure of work relations between groups of people holding positions that work in a certain way to jointly achieve certain goals. According to Pradjudi Robbins, (2012) organization is the structure of the division of labor and the structure of work relations between a group of people holding positions that work together in a certain way to jointly achieve certain goals.

According to Roya (2014), organization is a form of human union to achieve a common goal. However, we need to understand that the basis of the organization is not "who" but "what" which means that it is not the person who will hold the organization that matters. but the "what" is the task of the organization.

"Organizational performance is the totality of the work achieved by an organization achieving the goals of the organization means that, the performance of an organization can be seen from the degree to which the organization can achieve goals based on the goals set previously". Pieter (2015) According to Yousef (2012) Organizational performance is something that has been achieved by the organization within a certain period of time, both related to input, output, outcome, benefit, and impact.

The concept of leadership has been offered by many authors in the field of organization and management. Leadership, of course, connects the individual aspects of a leader with the context of the situation in which the leader applies leadership. Leadership also has a collective nature in the sense that any behavior adopted by a leader will have a broad impact not on himself but on all members of the organization. The leader refers to a specific person or individual or noun. Meanwhile, leadership is the nature of the application of influence by a group member or organization to other members in order to encourage the group or organization to achieve its goals, Lussier, (2010). The role of the leader in the organization is one of the most important employee job satisfaction factors. The leader must be able to set goals, plan, organize, move and control all the resources they have. Leadership is the main thing in management which plays an important and strategic role for the survival of a company. Effective leadership can help organizations to survive in a situation of uncertainty in the future will come (Desianty, 2005).

Robbins and Judge (2015) leaders are people who have the task to direct and guide subordinates and are able to get subordinate support so that they can move subordinates towards achieving organizational goals. Leadership is the ability to influence a group towards achieving a vision or set goals . 


\section{IMPLEMENTATION METHOD}

This training uses experiential learning methods with interactive communication techniques, dialogues, discussions, role plays/games, where participants are introduced to concepts, then directly involved with feelings, experiences, discussing theprocess and results of this training to arouse the spirit of organizational performance and leadership spirit among students, especially administrators of Intra-School Student Organizations.

This training was held in collaboration with the Faculty of Economics and Business, Mercu Buana University (UMB) with intra-school Student organizations located in the Kembangan area. UMB helped provide speakers, seminar flyers, pre-post examinations, evaluations, and snacks, while the school helped send representatives of OSIS members, providing rooms, training equipment. Training participants are 30 participants in this activity.

Phase 1: Participant's initial test and initial assessment

After the opening ceremony and before the material was delivered, participants were asked to fill in the questionnaire as a preliminary test. Initial assessment of the participants is done by filling out the training registration form.

Phase 2: Submission of training material by the instructor

The training material consists of presentations, brainstorming, and dialogue. The selection of this method is carried out with the aim of achieving the desired targets of successful training in developing entrepreneurship

Phase 3: Post-test and feedback

Before closing, participants are asked to fill in a post-test, and evaluate the event, messages, and impressions of the participants as feedback .

The lecturer on team is assigned to deliver material and assistance, while students play a role to assist administration and provide ice breaking. This training is carried out in an integrated or combined in a place, because, the training method used is discussion and explore the abilities of each participant, making it possible to exchange ideas among fellow participants. This is positive in nature and will certainly invite the attention of the student council officials who have not participated. Hopefully, there will be other students to join in participating in the training activities. The training material includes: Participant Expectations, Introduction to Leadership, Management and Organizational Introduction, Problem Solving, and Ice Breaking.

\section{RESULTS AND DISCUSSION}

Community service activities in the form of training and coaching management and leadership are held with the aim of: First, providing understanding of management and organizational leadership for students. Second, it forms the character of leadership in themselves from an early age. Third, as an initial step in the process of coaching students that are intensive, ongoing and programmed. Fourth, forming student council management who have established managerial skills and are creative. The fifth anticipates students as mere political objects. Sixth, identify the political mindset of students and political activities that are allowed for students . Based on this purpose, this activity provides benefits in: First, the creation of an independent, creative and efficient student council. Second, it can help stakeholders in me managing the various activities. Third, increase the existence of schools through student activities . Fourth, the creation of a productive and useful community, especially the student council committee at the S LTA level.

Leadership is an attempt to influence followers not by force to motivate people to achieve certain goals. The relationship between a leader and a member is related to the degree of emotional quality of the relationship, which includes the level of intimacy and acceptance of members towards the leader. The more confident and believe members of the leader, the more effective groups in mencapa i goal. Important factors contained in the notion of leadership: (1) the utilization of influence, (2) human relationships, (3) the process of communication and (4) the achievement of a goal. Leadership depends on the strength of influence given and the intensity of the relationship between the leader and followers.

\section{CONCLUSION}

After the training is carried out, intensive coaching is carried out. Coaching is done by the method of attending school directly. The problem that was discussed at the time of coaching was a problem that was being faced by every student council board and together looking for a solution. This coaching was also carried out by involving several OSIS to gather with the method that more advanced schools provide input to other schools. In this case as the student council is considered established. The establishment of the student council is due to the regeneration process which is 
relatively functioning every year with training held by the school every year. This OSIS Leadership and organizational management training will produce a generation that is ready to lead the OSIS as a regeneration of OSIS and ready to be a leader in the community and at the organizational level at the university later.

The process of creating leadership characteristics that understand management has been instilled in all training participants. The stage of creating a leadership character that understands management well is not enough just to carry out one leadership training course, but must be carried out similar and linear training simultaneously. In addition, intensive coaching is also carried out. This simultaneous regeneration process will continue to be carried out in regeneration for each year, so a cadre culture will be created before the student council organizers recruit the student council in school.

The process of creating leadership that has character and has management understanding is very necessary and interrelated. The relationship between leadership and management is very close. Relationship which is closely involved work effortequally between two or more people, to achieve the goals set. Participative management is a management approach that involves subordinates in decision making processes. Active involvement of subordinates by using all their expertise and creativity in solving important management problems. The implementation of participatory management based on the shared authority of superiors and their subordinates does not mean that superiors delegate all of their authority or reduce their authority in decision making but rather include subordinates making decisions in solving important management problems

\section{REFERENCES}

Arief, Harefan \& Tama Putra Saratian, Eko. (2018). ENTREPRENEURIAL OPPORTUNITIES IN INDONESIA TO INITIATE BUSINESS THROUGH IMPORTER COMMUNITIES. ICCD. $1.446-454$. 10.33068/iccd.Vol1.Iss1.66.

Desianty, Sovyia. 2005. Pengaruh Gaya Kepemimpinan Terhadap Komitmen Organisasi Pada PT. Pos Indonesia Semarang. Jurnal Studi Manajemen dan Organisasi, 2(1):69-84.

Boer, Harry. (2001). Innovation, What Innovation? A Comparison between product, process and organizational innovation. International Journal of Technology Management - INT J TECHNOL MANAGE. 22. 83-107. 10.1504/IJTM.2001.002956.

Harold Koontz, Cyril O’Donnell dan Heinz Weihrich Manajemen; Jilid 1 Edisi Kedelapan;/Oleh.-Jakarta: Erlangga, 1996

Khazanchi, S., Lewis, M. W., \& Boyer, K. K. (2007). Innovation-supportive culture: The impact of organizational values on process innovation. Journal of operations management, 25(4), 871-884. http://dx.doi.org/10.1016/j.jom.2006.08.003

Kimberly, J. R., \& Evanisko, M. J. (1981). Organizational innovation: The influence of individual, organizational, and contextual factors on hospital adoption of technological and administrative innovations. Academy of Management Journal, 24(4), 689-713. http://dx.doi.org/10.2307/256170

Lussier N Robert (2010), Human Relation in Organization Applications and Skill Building. New York: Mc. Graw Hill.

Robbins, Stephen P. dan Timothy A. Judge. 2015. Perilaku Organisasi, Edisi 16. Jakarta: Salemba Empat.

Roya Yousefi. (2014), The Effect Of Knowledge Management On Organizational Learning And Performance Of Education Department Of Abhar County. Kuwait Chapter of Arabian Journal of Business and Management Review Vol 3. No.12a; August. 2014.

Soelton, Mochamad, Nugrahati, Tati, 2018. How Complaining Behaviors Effect on Coping Stress and Anxiety?. International Journal of Saudi Journal of Business and Management Studies (SJBMS). Vol. 3, No. 6. 623-628.

Soelton et al, 2019. Gender : Stress Levels On Performance In Modern Industry. International Journal Archives of Business Research (United Kingdom). Vol. 7, No 2. 72-81

Soelton et al, 2018. Toward The Best Strategy In Minimizing The Spread of Drug Users. International Conference On Community Development In Asia. Vol 1. No 1. 171-176

Tama Putra Saratian, Eko \& Arief, Harefan. (2018). ENTREPRENEURIAL OPPORTUNITIES IN INDONESIA TO INITIATE BUSINESS THROUGH IMPORTER COMMUNITIES. ICCD. 1. 446-454. 10.33068/iccd.Vol1.Iss1.66.

Yousef, Darwis A. (2012). Organizational Commitment: A Mediator of the Relationship of Leadership Behavior with Job Satisfaction and In a Non Western Country, Journal of Managerial Psychology, Vol. 15 (4): 6-28. 